\title{
KORELASI PSYCHOLOGICAL WELL-BEING DENGAN BURNOUT PADA PERAWAT RUMAH SAKIT JIWA PROF.ILDREM PEMPROVSU MEDAN
}

\author{
Togi Fitri A Ambarita \\ Dosen Kopertis DPK Fakultas Psikologi Universitas HKBP NOmmensen \\ e-mail: tree_psy@hotmail.com
}

\begin{abstract}
ABSTRAK
Psychological well-being menjelaskan konsep kebahagiaan dikaitkan dengan kebutuhan akan keberadaan/eksistensi individu ditengah kehidupan yang penuh permasalahan. Tokoh yang mengembangkan konsep psychological well-being adalah Ryff, dimana dia menjelaskannya hal tersebut dalam enam aspek. Enam aspek psychological well-being tersebut yakni; Self-Acceptance, Positive Relation with other, Autonomy, Environmental Mastery, Purpose in life dan Personal Growth. Penelitian ini adalah penelitian korelasional untuk melihat hubungan antara psychological well-being dengan Burnout pada perawat di Rumah Sakit Jiwa Dr. Ildrem Pemprovsu Medan. Burnout merupakan sindrom kelelahan mental yang bersifat klinis yang dialami oleh pekerja dibidang layanan masyarakat yang mendapatkan apresiasi yang minimal terhadap layanan yang sudah diberikannya. Sampel penelitian berjumlah 54 orang perawat PNS di Rumah Sakit Jiwa Pemprovsu. Karakteristik sampel penelitian antara lain, lebih dari $70 \%$ berusia 40 tahun keatas dimana lebih dari $70 \%$ sampel penelitian memiliki pengalaman kerja yakni 10 tahun keatas. Hasil Uji korelasi dengan product moment menunjukkan bahwa ada korelasi yang negative antara psychological well-being dengan Burnout pada perawat di Rumah Sakit Jiwa Prof. Ildrem Pemprovsu Medan. Dengan demikian semakin tinggi psychological well-being semakin rendah tingkat burnout.
\end{abstract}

Kata Kunci: Burnout, Psychological well-being, Perawat Jiwa

\section{PENDAHULUAN}

Kesehatan jiwa masih menjadi salah satu permasalahan kesehatan yang signifikan di dunia, termasuk di Indonesia. Faktanya, satu dari empat orang dewasa akan mengalami masalah kesehatan jiwa pada satu waktu dalam hidupnya. Data laporan WHO tahun
2013 menunjukkan, terdapat sekitar 35 juta orang terkena depresi, 60 juta orang terkena bipolar, 21 juta terkena skizofrenia, serta 47,5 juta terkena demensia. Di Indonesia, menimbang dari berbagai faktor biologis, psikologis dan sosial dengan keanekaragaman 
penduduk di Indonesia, maka jumlah kasus gangguan jiwa terus bertambah yang berdampak pada penambahan beban negara dan penurunan produktivitas manusia untuk jangka panjang. Berdasarkan hasil Riset Kesehatan Dasar (Riskesdas) Kemenkes tahun 2013, prevalensi gangguan mental emosional yang ditunjukkan dengan gejala-gejala depresi dan kecemasan untuk usia 15 tahun keatas mencapai sekitar 14 juta orang atau 6\% dari jumlah penduduk Indonesia. Sedangkan prevalensi gangguan jiwa berat, seperti skizofrenia mencapai sekitar 400.000 orang atau sebanyak 1,7 per 1.000 penduduk. Kemudian peningkatan proporsi gangguan jiwa pada data yang didapatkan Riskesdas 2018, cukup signifikan jika dibandingkan dengan Riskesdas 2013, naik dari 1,7\% menjadi $7 \%$. Dengan demikian usaha penanganan penyakit jiwa sudah selayaknya menjadi perhatian utama. (Matta, 2016).

Usaha penanganan masalah kesehatan jiwa tidak lepas juga dari kualitas tenaga professional kesehatan jiwa. Tenaga kesehatan jiwa antara lain yakni dokter jiwa, perawat jiwa, psikolog atau tenaga profesional lainnya. Saat ini Indonesia, dengan penduduk sekitar 250 juta jiwa, baru memiliki sekitar 451 psikolog klinis $(0,15$ per 100.000 penduduk), 773 psikiater $(0,32$ per 100.000 orang), dan perawat jiwa 6.500 orang (2 per 100.000 orang) (Matta, 2016).

Perawat jiwa merupakan tenaga kesehatan jiwa yang lebih banyak dijumpai terutama di Rumah Sakit Jiwa, dimana mereka yang paling sering melakukan kontak langsung dengan pasien-pasien jiwa yang sedang mengalami perawatan khususnya di Rumah Sakit jiwa. Kesehatan mental dari para perawat ini merupakan hal yang penting yang harus diperhatikan agar mereka mampu melakukan tugasnya dengan optimal.

Perawat jiwa yang memiliki tugas merawat pasien gangguan jiwa tentunya menjadi lebih berbeda dengan perawat yang memiliki tugas merawat pasien gangguan fisik. Perawat yang menangani pasien dengan gangguan jiwa membutuhkan ketelatenan dan kesabaran yang tinggi karena karakteristik pasien gangguan jiwa yang unik seperti sulit diajak berkomunikasi, menarik diri, atau bahkan cenderung agresif, sehingga menjadi pertimbangan bagi perawat dalam memberikan asuhan keperawatan (Asmadi, dalam Siswati 2018 ). Selain itu, proses pengobatan pada pasien dengan gangguan jiwa memerlukan waktu yang lama, sehingga asuhan keperawatan yang dilakukan sangat menentukan keberhasilan pengobatan (Keliat, dalam Siswati 2018).

Hasil penelitian menunjukkan bahwa perawat yang bekerja di bagian jiwa memiliki resiko yang lebih tinggi mengalami kelelahan mental (Chakraborty, Chatterjee, Chaudhury, 2012 dalam Kholifah dkk 2016). Beberapa penelitian mengindikasikan bahwa angka kejadian perawat jiwa mengalami kelelahan mental lebih tinggi dibandingkan perawat dari bagian lain (Madhatil, Heck dan Schulberg, 2014 dalam Kholifah 2016). Kelelahan, yang tidak hanya fisik, namun emosional dan mental yang dialami seseorang yang disebabkan keterlibatan jangka panjang dalam situasi yang penuh dengan tuntutan emosional, merupakan bentuk sindrom stress akut atau disebut sebagai sindrom Burnout (Pines dan Aronson, dalam Sutjipto, 2001). Berdasarkan penelitian yang dilakukan oleh Fuente et al (2014 dalam Kholifah dkk 2016), 
pervalensi terjadinya kelelahan mental pada perawat jiwa di spanyol cukup tinggi dimana sepertiga dari total responden mengalami Burnout dengan rata-rata $25 \%$ pada dimensi kelelahan emosional, $30 \%$ pada dimensi depersonalisasi, dan $45 \%$ pada dimensi prestasi diri. Hasil yang sama ditunjukkan dalam penelitian Acker (2012) terhadap 460 perawat jiwa di Amerika Serikat bahwa 56\% diantaranya mengalami kelelahan emosi dan $73 \%$ mengelami stress pada level sedang.

Hasil penelitian yang dilakukan oleh Ramdan (2016) menunjukkan 56\% perawat di RS AH Samarinda mengalami burnout. Penelitian lainnya oleh Nugroho dkk (2012) di Rumah Sakit Jiwa Menur, surabaya, ditemukan Burnout pada perawat jiwa termasuk dalam kategori rendah $(68,3 \%)$ dan sangat rendah $(26,8 \%)$. Penelitian pada perawat jiwa di rs jiwa povinsi Kalimantan barat, menunjukkan tingkat Burnout pada perawat pelaksana dalam kategori rendah sebesar $82,8 \%$ dan kategori sedang sebesar 17,2\% (Eliyana, 2016). Penelitian yang dilakukan Triyana (2020), diperoleh hasil bahwa Burnout pada perawat kesehatan jiwa yang praktik di RSJ Dr. Soeharto Heerdjan, Jakarta berada pada kategori sedang. Hasil penelitian menunjukkan bervariasinya tingkat Burnout pada perawat jiwa di Indonesia. Dengan demikian sindrom Burnout perlunya dikaji lebih lanjut terkait sindrom Burnout pada perawat jiwa.

Sementara itu, dalam sebuah portal RS Jiwa Bangka Belitung, diuraikan bahwa perawat kesehatan jiwa dan terapis okupasi mengalami stres kerja [burnout] menempati angka tertinggi yaitu $54 \%$ dibandingkan psikolog, dokter umum, residen dan pengasuh anak. Hasil studi mengindikasikan bahwa perawatperawat di bangsal jiwa menunjukkan level yang lebih tinggi dibandingkan bekerja di bangsal internal, bedah, dan luka bakar. Burnout mengakibatkan penurunan kinerja, performa perawat jiwa dan peningkatan kesalahan memberikan asuhan keperawatan. Perawat di bangsal jiwa terindikasi mengalami kelelahan emosional, depersonalisasi, dan masalah prestasi pribadi yang lebih dominan.

Sindrom utama dari Burnout
adalah kelelahan mental, dimana Burnout yang tinggi cenderung akan mengembangkan depresi. Kelelahan mental dapat dipengaruhi oleh factor internal maupun factor eksternal. Dimana factor internal ini sangat penting untuk diketahui karena factor internal mempengaruhi proses penilaian individu terhadap factor eksternal (Kholifah, 2016). Hasil penelitian oleh Hsieh dan Wang (2012 dalam Kholifah 2016), menunjukkan hasil bahwa factor internal memiliki signifikansi lebih tinggi daripada factor eksternal dalam menentukan resiko seseorang mengalami kelelahan mental. Factor internal yang dimaksud adalah factor yang ada dalam diri perawat itu sendiri, serpti kematangan emosi, penyesuaian diri dan termasuk juga kualitas kesejahteraan psikologis atau disebut dengan psychological well-being.

Psychological well-being menjelaskan kebahagiaan berkaitan dengan kebutuhan akan keberadaan/eksistensi individu ditengah kehidupan yang penuh permasalahan (Keyes, Shmotkin, \& Ryff, 2002 dalam Singh, 2012). Dalam bidang ilmu psikologi, psychological well-being menjadi kajian penting yang diteliti dalam menjelaskan kesehatan mental. 
Tokoh yang terkenal mengembangkan psychological well-being adalah Ryff (dalam Singh 2012), dimana dia menjelaskan aspek psychological wellbeing melalui 6 dimensi. Keenam dimensi tersebut antara lain, penerimaan diri, hubungan yang positif dengan orang lain, pertumbuhan pribadi, environmental mastery dan autonomi.

Kholifah (2016), meneliti tentang hubungan factor-faktor internal penyebab Burnout pada perawat jiwa di rumah sakit Dr. Radjiman Wediodiningrat Mental Hospital di Lawang. Hasilnya menunjukkan bahwa faktor psychological well-being merupakan factor internal yang memiliki korelasi signifikan terhadap sindrom burnout, yakni semakin tinggi psychological well-being semakin rendah sindrom burnout. Sementara penelitian lainnya tentang psychological well-being pada perawat jiwa yang dilakukan di rumah sakit jiwa semarang, menunjukkan bahwa kemampuan individu mengelola emosi dengan menampilkannya sesuai tuntutan pekerjaan, memiliki korelasi yang positif terhadap psychological well-being (Siswati, 2018). Semakin tinggi kemampuan untuk mengelola emosi maka semakin tinggi psychological wellbeing perawat jiwa.

Dengan latar belakang yang diuraikan diatas maka peneliti tertarik melakukan kajian terkait kesehatan mental pada perawat jiwa. Rumah sakit jiwa daerah di kota Medan yakni RSJ Prof Ildrem merupakan rumah sakit jiwa yang terbesar di kota Medan, yang memiliki jumlah perawat jiwa yang cukup besar. Rumah sakit ini termasuk rumah sakit utama yang memberikan layanan untuk kesehatan jiwa masyarakat medan. Dengan demikian dirasakan sangat penting melakukan penelitian terkait kesehatan mental perawat jiwa di rumah sakit jiwa tersebut.

Sesuai dengan uraikan di latar belakang maka dilakukanlah penelitian deskriptif mengukur sindrom Burnout dan kualitas psychological well-being perawat jiwa. Kemudian peneliti juga melakukan analisis terkait korelasi kualitas psychological well-being terhadap tingkat Burnout pada perawat jiwa di Rumah Sakit Jiwa Prof. Ildrem.

\section{II.2. Psychological well-being}

$$
\text { Psychological well-being }
$$

merupakan konsep yang berusaha menjelaskan manusia yang memiliki mental yang sehat atau manusia dengan kepribadian yang baik, dimana hal ini memiliki kesamaan dengan konsep aktualisasi diri dari abraham maslow, manusia yang mampu berfungsi maksimal/ sepenuhnya dari roger, individuasi dari Jung, maturity dari Allport dan juga sama halnya menjelaskan manusia dewasa yang mampu melalui dengan sukses setiap tugas-tugas tahapan perkembangan (Snyder, 2003).

Elemen psychological well-being dikembang Ryff ( 1981; dalam Snyder 2003, dalam Hefferon, 2011 ) menjadi 6 dimensi, yakni:

\section{Self-Acceptance}

Penerimaan diri atau self-acceptance merupakan karakter yang penting dalam menjelaskan mental yang sehat, sama seperti konsep aktualisasi diri dari Abraham Maslow, konsep berfungsi optimal dari Carl Rogers. Teori-teori tentang perkembangan juga menjelaskan penerimaan akan diri sendiri dan penerimaan akan pengalamanpengalaman kehidupan di masa lalu 
berperan penting dalam pembentukan kedewasaan.

\section{Positive Relation with other}

Kemampuan untuk mencintai orang lain, merupakan komponen utama dalam kesehatan mental. Kemampuan untuk self aktualisasi digambarkan sebagai situasi memiliki perasaan yang kuat terhadap empati dan afeksi kepada sesama manusia dan perasaan cinta yang besar dengan orang lain, pertemanan yang akrab dan bentuk-bentuk relasi akrab lainnya dengan orang lain.

3. Autonomy

Autonomi berkaitan dengan kemampuan self determination, independensi dan regulasi perilaku dari dalam diri. Aktualisasi diri, digambarkan sebagai keberfungsian diri yang bekerja secara mandiri dan resisten terhadap budaya. Orang yang berfungsi sepenuhnya juga ditandai dengan evaluasi diri yang bersifat internal, tidak sebagai usaha mendapatkan penerimaan orang lain, tapi lebih sebagai bentuk evaluasi diri sendiri.

\section{Environmental Mastery}

Kemampuan individu untuk memilih atau membentuk lingkungan yang sesuai dengan kondisi psikis seseorang. Kemampuan untuk mampu memanipulasi dan mengkontrol lingkungan yang kompleks. Kemampuan lanjut untuk mengubah lingkungan secara kreatif, melalui suatu aktivitas fisik atau mental.

5. Purpose in life

Memiliki tujuan hidup yang jelas, memiliki arah, dan intensionalitas. Bervariasi perubahan tujuan dalam hidup, seperti menjadi produktif, kreatif atau mencapai integritas emosi.

6. Personal Growth

Karakter mental yang sehat, tidak hanya tentang fungsi psikologis yang mampu mencapai tujuannya tapi juga bicara tentang kemampuan untuk mengembangkan potensi yang dimilikinya, bertumbuh dan mengembangkan dirinya. Terbuka akan perubahan merupakan contoh dari karaktersitik kunci dari seseorang yang berfungsi sepenuhnya. Seperti seorang individu yang secara kontiniu terus berkembang, bukan stagnasi atau diam setelah penyelesaian suatu masalah telah dicapai.

Berdasarkan hasil penelitian Gallup Organization, Rath dan Harter (2010, dalam Hefferon dkk) menjelaskan ada 5 elemen yang esensial untuk mencapai "Well-being":

01. Sejahtera dalam karir: hal ini tampak ketika seesorang terlibat secara intens atau memiliki ketertarikan yang tinggi untuk terlibat melakukan pekerjaannya selama jam kerja beralngsung.

02. Sejahtera dalam kehidupan sosial: hal ini tampak dari relasi sosial yang dibina dengan orang lain dan pengalaman kepedulian atau cinta pada orang lain.

03. Sejahtera dalam hal keuangan: hal ini tampak dari sejauhmana sesorang itu mampu memanajemen keuangannya.

04. Sejahtera dalam hal fisik: hal ini tampak dari kemampuanmu untuk merasa sehat dan berenergi.

05. Sejahtera dalam hal komunitas: hal ini tampak dari adanya peran dan partisipasi dalam komunitas atau kelompok di lingkungan kerja atau masyarakat.

\section{II.2. Burnout}

Istilah Burnout pertama kali diperkenalkan kepada masyarakat oleh Herbert Freudenberger pada tahun 1973 yang kemudian dikenal sebagai bapak penemu sindrom burnout. Tulisannya berpengaruh dalam memperkenalkan konsep burnout. Freudenberger adalah seorang psikiatris yang bekerja dalam sebuah klinik amal untuk ketergantungan obat. Rata-rata staff yang bergabung 
dalam klinik amal tersebut kebanyakan relawan muda yang identik dengan motivasi. Freudenberger mengamati bahwa banyak anggota relawan tersebut setelah bekerja selama 1 tahun kehabisan energi dan kehilangan motivasi dan komitmen, disertai dengan ditunjukkannya bermacam-macam sindrom emosi dan fisik. Freudenberger memilih kata 'burnout' untuk memberi label atas kondisi tersebut dimana kata ini biasanya digunakan untuk menunjukkan efek kronik dari penyalahgunaan obat (Ambarita, 2013). Penelitian tentang Burnout sendiri sebenarnya telah berlangsung selama 25 tahun (Maslach, dkk, 2001) sehingga menghasilkan berbagai ragam pengertian. Dalam Lexicon of Psikiatri \& Mental Health terms (1994) dinyatakan bahwa sindrom Burnout merupakan salah satu bentuk reaksi ekstrim terhadap stres yang berkaitan dengan kerja, dan istilah ini masih kontroversial dan beberapa pengarang memasukkannya sebagai kasus depresi klinis.

Maslach dan Jackson (dalam Sutjipto, 2001) meneliti tentang Burnout pada bidang pekerjaan yang berorientasi melayani orang lain seperti bidang kesehatan mental, bidang pelayanan kesehatan, bidang pelayanan sosial, bidang penegakan hukum, maupun bidang pendidikan; dalam perkembangannya telah memberikan sumbangan yang sangat berarti dalam memahami burnout. Mereka menemukan bahwa Burnout merupakan suatu pengertian yang multidimensional. Maslach (dalam Sutjipto, 2001) mengartikan Burnout sebagai sindrom psikologis yang terdiri atas tiga dimensi yaitu kelelahan emosional, depersonalisasi, dan "low personal accomplishment".
Sementara itu Pines dan Aronson (dalam Sutjipto, 2001) mendefinisikan Burnout sebagai kelelahan secara fisik, mental, dan emosional karena keterlibatan yang lama dalam situasi yang menuntut secara emosional. Burnout dialami oleh seseorang yang bekerja di sektor pelayanan sosial dalam waktu yang cukup lama. Menurut mereka, pada jenis pekerjaan tersebut, seseorang menghadapi tuntutan dari klien, tingkat keberhasilan dari pekerjaan rendah, dan kurangnya penghargaan yang adekuat terhadap kinerja pemberi layanan. Seorang yang bekerja melayani orang lain (caregiver), yang menghadapi tuntutan-tuntutan dari si penerima layanan, menggambarkan keadaan yang menuntut secara emosional (emotionally demanding), sehingga pada akhirnya dalam jangka panjang tertentu seseorang akan mengalami kelelahan, karena ia berusaha memberikan sesuatu secara maksimal, namun memperoleh apresiasi yang minimal.

Maslach dan Jackson (dalam Sarafino, 2008; Maslach dan Leiter 1997) menjelaskan tiga komponen tersebut, sbb:

\section{Kelelahan Emosional}

Pada kondisi ini rasa lelah muncul begitu saja, si penderita mudah merasa lelah, meskipun sebelumnya tidak ada keluar energy yang cukup berarti. Rasa lelah ini tidak mudah hilang, meskipun individu sudah istirahat beberapa hari. Jika dalam kondisi stress biasa, dengan mengurangi aktivitas dan beristirahat beberapa hari, biasanya energi akan mudah muncul kembali sehingga bersemangat untuk segera beraktivitas. Pada orang yang menderita burnout, rasa lelah emosional cenderung masih menetap, bahkan saat bangun tidur (bangun tidur di pagi hari), dimana 
penderita belum melakukan aktivitas berarti.

\section{Depersonalisasi}

Suatu kondisi dimana individu/ penderita Burnout ingin menjauh atau menghilang dari lingkungan, bahkan tidak mempedulikan orang-orang disekitarnya dan bersikap negative. Kondisi sebelumnya penderita Burnout merupakan seseorang yang memiliki kepedulian yang cukup tinggi pada orang lain/ orang yang dilayani. Dengan kata lain, dia menjadi pribadi yang berbeda dari sebelumnya. Bahkan, individu menjadi sinis terhadap lingkungan disekitarnya, tidak mampu bersikap empati bahkan cenderung menjadi tidak peduli pada orang lain/ lingkungan.

\section{Feeling of low accomplishment}

Suatu kondisi dimana individu merasa tidak mampu, atau tidak puas terhadap kemampuannya dalam melakukan tugas yang diberikan padanya. Evaluasi negative terhadap kemampuan diri ini muncul sebagai reaksi dari depersonalisasi. Depersonalisasi yang ditandai dengan sikap-sikap negative atau sinisme terhadap pasien (oleh perawat), bahkan individu menyadari dia menjadi seorang yang bersikap "dingin" atau bahkan tidak berperasaan kepada orang yang dilayaninya (pasien). Dengan kondisi demikian, individu kemudian mengembangkan "feeling of low accomplishment" yakni pekerja merasa dirinya tidak kompeten, tidak efektif, tidak adekuat, merasa kurang puas dan kurang mampu melakukan tugas-tugas dalam bekerja, bahkan muncul perasaan kegagalan dalam melakukan pekerjaan (Maslach dan Leiter, 1997)

\section{METODE PENELITIAN}

Jenis penelitian adalah metode korelasional, dengan menggunakan pendekatan kuantitatif, yakni mendeskripsikan mengenai hubungan atau korelasi antara psychological wellbeing dengan Burnout pada perawat jiwa di rumah sakit jiwa Pemprovsu Prof. Ildrem Medan. Pendekatan kuantitatif digunakan untuk menguji hipotesis yang telah ditetapkan, dimana dalam penelitian ini dilakukan pengujian hubungan dua variable atau penelitian korelasional (Sugiyono, 2008).

Variable Penelitian

Penelitian ini merupakan penelitian dengan dua variabel yakni psychologycal well-being dan burnout.

Defenisi operasional untuk masingmasing variable yakni:

- Psychological well-being adalah bentuk eudamonic well-being yakni perasaan bahagia yang dirasakan seseorang yang muncul akibat pengalaman kepuasaan pribadi ketika dia mampu memfungsikan dirinya secara optimal dan merasa bermakna dalam hidupnya, dimana dalam penelitian ini, Psychological wellbeing perawat jiwa diukur dengan skala PWB ,yang diekmbangkan dari skala PWB dari Ryff .

- Burnout adalah sindrom klinis, reaksi akibat stres kerja atau kelelahan kerja, ditandai 3 simptom yakni kelelahan emosi, depersonalisasi dan low personal accomplishment, yang dialami perawat jiwa di rumah sakit jiwa pemprovsu medan, dimana sindrom Burnout diukur melalui skala MBI (Maslach Burnout Inventory). 
Populasi dan Sampel Penelitian

Karakteristik subjek penelitian adalah perawat jiwa, pegawai menetap (PNS), minimal sudah bekerja satu tahun di Rumah Sakit tersebut. Sampel penelitian berjumlah 54 orang dari total 137. Jumlah ini memenuhi persyaratan tentang jumlah minimal ukuran sampel sebuah penelitan (Roscoe dalam Sekaran \& Bougie, 2016). Jumlah ini juga memenuhi kriteria jumlah sampel menurut Slovin, dengan level tingkat kepercayaan 95\%. Kemudian yang dipilih menjadi sampel penelitian adalah perawat yang dijumpai saat pengambilan sampel, jadi tidak semua individu dalam populasi memperoleh peluang untuk menjadi sampel dengan demikian teknik sampling yang digunakan non random, accidental.

Jenis Data dan Alat Pengumpulan Data Jenis data dalam penelitian ini adalah kuantitatif. Data kuantitatif yang digunakan adalah hasil penghitungan data yang menggambarkan Burnout dan tingkat Psychological well-being pada perawat di Rumah Sakit Jiwa Pemprovsu Medan, dengan menggunakan penghitungan statistik deskriptif. Jenis data merupakan data primer, data yang diambil langsung oleh peneliti yang kemudian di olah dengan statistic.

Teknik pengumpulan data adalah dengan menggunakan skala PWB dan Skala Burnout. Data PWB diperoleh melalui Skala PWB, yakni skala model likert yang dikembangkan peneliti berdasarkan elemen-elemen psychological well-being yang dikembangkan oleh Ryff. Validitas melalui uji daya beda aitem dengan $r$ berkisar 0,25 sampai 0,60. Relibilitas dengan cronbach alpha sebesar 0,87 .
Pengukuran Burnout dilakukan dengan menggunakan skala Maslach Burnout Inventory. Skala yang sudah baku, yang digunakan kurang lebih 25 tahun, dengan tingkat validitas dan reliabilitas cukup baik. Dimana tingkat reliabilitas menurut alpha cronbach yakni 0.90 untuk dimensi emotional exhaustion, 0.76 dimensi Depersonalization, dan 0.76 untuk dimensi Personal Accomplishment .

Uji Hipotesis

Setelah dilakukan pengolahan data statistic deskriptif lalu dilakukan uji hipotesis untuk melihat korelasi dengan menggunakan uji statistik pearson product moment.

\section{HASIL DAN PEMBAHASAN}

Subjek penelitian berjumlah 54 orang perawat PNS di Rumah Sakit Jiwa. Berikut ini diuraikan data demografi sampel penelitian berdasarkan hasil penelitian.

Tabel 1. Sebaran data sampel berdasarkan Jenis Kelamin

\begin{tabular}{|c|c|c|c|}
\hline $\begin{array}{c}N \\
\mathrm{O}\end{array}$ & $\begin{array}{c}\text { Jenis } \\
\text { Kelamin }\end{array}$ & $\begin{array}{c}\text { Jumlah } \\
\text { (orang) }\end{array}$ & $\begin{array}{c}\text { Persentase } \\
(\%)\end{array}$ \\
\hline 1 & Perempuan & 45 & 83 \\
\hline 2 & Laki-laki & 9 & 17 \\
\hline & Total & 54 & \\
\hline
\end{tabular}

Tabel 2. Sebaran data sampel berdasarkan usia

\begin{tabular}{|c|c|c|c|}
\hline NO & $\begin{array}{c}\text { Usia } \\
\text { (tahun) }\end{array}$ & $\begin{array}{c}\text { Jumlah } \\
\text { (orang) }\end{array}$ & $\begin{array}{c}\text { Persentasi } \\
(\%)\end{array}$ \\
\hline 1 & $\underline{21-30}$ & 4 & 7 \\
\hline 2 & $\underline{31-40}$ & 12 & 22 \\
\hline 3 & $\underline{41-50}$ & 22 & 40,7 \\
\hline 4 & $\underline{51-60}$ & 16 & 30,3 \\
\hline & $\underline{\text { Total }}$ & 54 & \\
\hline
\end{tabular}


Usia peserta penelitian dikisaran 21 sampai 55 tahun, yakni usia produktif kerja pada usia dewasa. Peserta penelitian $30 \%$ usia matang berada pada usia 51 - 55 tahun.

Tabel 3. Sebaran data sampel berdasarkan tingkat pendidikan

\begin{tabular}{|c|c|c|c|}
\hline $\begin{array}{l}\mathrm{N} \\
\mathrm{o}\end{array}$ & Pendidikan & $\begin{array}{c}\text { Jumlah } \\
\text { (orang) }\end{array}$ & $\begin{array}{c}\text { Persentasi } \\
(\%)\end{array}$ \\
\hline 1 & $\underline{\mathrm{D} 3}$ & 17 & 31 \\
\hline 2 & $\underline{\text { S1 }}$ & 37 & 69 \\
\hline & $\underline{\underline{\text { Total }}}$ & 54 & \\
\hline
\end{tabular}

Tabel 4. Sebaran data sampel berdasarkan Agama

\begin{tabular}{|c|c|c|c|}
\hline No. & Agama & $\begin{array}{c}\text { Jumlah } \\
\text { (orang) }\end{array}$ & $\begin{array}{c}\text { Persenta } \\
\text { si } \\
(\%)\end{array}$ \\
\hline 1 & $\underline{\text { Kristen }}$ & 25 & 46 \\
\hline 2 & $\underline{\text { Katolik }}$ & 6 & 11 \\
\hline 3 & $\underline{\text { Islam }}$ & 20 & 37 \\
\hline 4 & $\underline{\text { Lainnya }}$ & 3 & 6 \\
\hline & $\underline{\text { Total }}$ & 54 & \\
\hline
\end{tabular}

Sampel penelitian paling banyak menganut agama kristen yakni 46\%, sementara yang lainnya beragama islam, katolik atau agama lainnya.

Tabel 5. Sebaran sampel berdasarkan suku

\begin{tabular}{|c|c|c|c|}
\hline NO & Suku & $\begin{array}{c}\text { Jumlah } \\
\text { (orang) }\end{array}$ & $\begin{array}{c}\text { Persentas } \\
\text { i } \\
(\%)\end{array}$ \\
\hline 1 & Batak & 39 & 72 \\
\hline 2 & Jawa & 5 & 9 \\
\hline 3 & $\underline{\text { Melayu }}$ & 2 & 4 \\
\hline 4 & Aceh & 2 & 4 \\
\hline 5 & $\underline{\text { Lainnya }}$ & 6 & 11 \\
\hline & & 54 & \\
\hline
\end{tabular}

Sampel penelitian paling banyak berasal dari suku batak yakni $72 \%$, sementara yang lainnya berasal dari suku jawa, melayu, dan Aceh, dari suku lainnya.
Tabel 6. Sebaran data sampel berdasarkan Lama Bekerja

\begin{tabular}{|l|c|c|c|}
\hline NO & Rentang Waktu & $\begin{array}{c}\text { Jumlah } \\
\text { (orang) }\end{array}$ & $\begin{array}{c}\text { Persentasi } \\
(\%)\end{array}$ \\
\hline 1 & $\underline{2-9 \text { tahun }}$ & 14 & 26 \\
\hline 2 & $\underline{10 \text { tahun keatas }}$ & 40 & 74 \\
\hline & $\underline{\text { Total }}$ & 54 & \\
\hline
\end{tabular}

Peserta penelitian $74 \%$ telah menjadi perawat di RS Jiwa diatas sepuluh tahun.

\section{HASIL UTAMA}

Gambaran Hasil Psychological wellbeing

Data hasil penelitian yakni skor PWB yang diperoleh setiap peserta digolongkan dalam 3 kategori yakni tingkat rendah, sedang, dan tinggi. Berikut ini gambaran hasil Skor PWB Perawat di Rumah Sakit Jiwa Pemprovsu.

Tabel. 7. Sebaran Tingkatan PWB

\begin{tabular}{|c|c|c|c|}
\hline NO & Kategori PWB & $\begin{array}{c}\text { Jumlah } \\
\text { (orang) }\end{array}$ & $\begin{array}{c}\text { Persentasi } \\
(\%)\end{array}$ \\
\hline 1 & $\underline{\text { Rendah }}$ & 0 & \\
\hline 2 & $\underline{\text { Sedang }}$ & 20 & 37 \\
\hline 3 & $\underline{\text { Tinggi }}$ & 34 & 63 \\
\hline & $\underline{\text { Total }}$ & 54 & \\
\hline
\end{tabular}

Penelitian PWB yang dilakukan pada perawat di Rumah Sakit Jiwa Pemprovsu menunjukkan hasil bahwa tingkat psychological well-being berada pada kategori sedang hingga tinggi, dimana tidak ada perawat yang berada pada level rendah. Dengan demikian dapat dikatakan secara umum psychological well-being perawat di Rumah Sakit Jiwa Pemprovsu dimaknai dengan cukup baik.

\section{Gambaran Tingkat Burnout}


Sindrom Burnout digambarkan dengan kemunculan 3 aspek yakni dimulai dari gejala kelelahan emosi, lalu depersonalisasi kemudian menurunnya kompetensi untuk berinteraksi secara efektif dengan pasien-pasien pada perawat.

Dari hasil penelitian, secara umum skor Burnout untuk perawat dirumah sakit jiwa pemprovsu pada kategori rendah, meskipun beberapa perawat, ada yang skornya cukup tinggi yakni pada aspek depersonalisasi dan efektifitas kerja.

Berikut ini gambaran tingkat Burnout pada perawat di rumah sakit jiwa pemprovsu, berdasarkan aspek-aspek burnout, sbb:

Tabel. 8. Tingkat Burnout per aspek

\begin{tabular}{|c|c|c|c|}
\hline $\begin{array}{c}\text { Level } \\
\text { Burno } \\
\text { ut }\end{array}$ & \multicolumn{3}{|c|}{ Aspek } \\
\cline { 2 - 4 } Kelelaha & $\begin{array}{c}\text { Depersonalis } \\
\text { asi }\end{array}$ & $\begin{array}{c}\text { Rendahny } \\
\text { a } \\
\text { Efektivitas } \\
\text { Pelayana } \\
\mathrm{n}\end{array}$ \\
\hline $\begin{array}{c}\text { Renda } \\
\text { h }\end{array}$ & 54 & 46 & 50 \\
\hline $\begin{array}{c}\text { Sedan } \\
\text { g }\end{array}$ & 0 & 5 & 1 \\
\hline Tinggi & 0 & 3 & 3 \\
\hline Total & 54 & 54 & 54 \\
\hline
\end{tabular}

\section{Korelasi Psychological well-being terhadap tingkat Burnout}

Hasil pengujian hipotesa dilakukan dengan uji korelasi pearson product moment dengan bantuan aplikasi SPSS. Hasil uji korelasi adalah sbb:

Tabel. 9. korelasi PWB terhadap Burnout

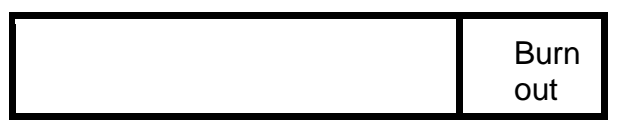

\begin{tabular}{|ll|l|}
\hline PWB & $\begin{array}{l}\text { Pearson } \\
\text { Correlation }\end{array}$ & - \\
& & $.373^{*}$ \\
& Sig. (2-tailed) & .006 \\
$\mathrm{~N}$ & 54 \\
\hline $\mathrm{N}$ & 54 \\
\hline
\end{tabular}

Tabel. 10. Korelasi tiap aspek PWB

\begin{tabular}{|l|l|l|}
\hline Aspek PWB & $\begin{array}{l}\text { Korelasi } \\
\text { burnout }\end{array}$ & Ket \\
\hline Autonomy & $-.369^{* *}$ & Signifikan \\
\hline Env Mastery & -.181 & $\begin{array}{l}\text { Tidak } \\
\text { Signifikan }\end{array}$ \\
\hline Personal Growth & -.250 & $\begin{array}{l}\text { Tidak } \\
\text { Signifikan }\end{array}$ \\
\hline $\begin{array}{l}\text { Positive } \\
\text { Relation }\end{array}$ & -.248 & $\begin{array}{l}\text { Tidak } \\
\text { Signifikan }\end{array}$ \\
\hline Purpose In life & $-.404^{* *}$ & Signifikan \\
\hline Self-acceptance & $-.307^{*}$ & Signifikan \\
\hline
\end{tabular}

**. Correlation is significant at the 0.01 level (2tailed)

. *. Correlation is significant at the 0.05 level (2tailed).

Pembahasan

Hasil penelitian menunjukkan korelasi yang signifikan antara psychological well-being terhadap burnout, dimana arah hubungannya negative. Dengan demikian artinya semakin tinggi psychological well-being maka kemunculan gejala burnout semakin kecil. Berdasarkan hasil tersebut dapat disimpulkan bahwa kondisi psikologis yang baik dapat menjadi salah satu indicator menghambat atau menurunkan tingkat burnout pada perawat. Hasil ini sejalan dengan penelitian Kholifah (2016) menghasilkan bahwa faktor psychological well-being merupakan factor internal yang memiliki korelasi signifikan terhadap sindrom burnout, 
yakni semakin tinggi psychological wellbeing semakin rendah sindrom burnout.

Ditinjau dari karakteristik sampel penelitian, perawat di Rumah Sakit Jiwa Pemprovsu lebih dari $70 \%$ merupakan perawat dengan pengalaman kerja yang cukup lama (diatas sepuluh tahun) dan usianya juga sudah matang atau usia dewasa madya (kebanyakan usia diatas 40 tahun). Setidaknya dari dua aspek ini tampak bahwa sampel penelitian merupakan pribadi-pribadi yang secara psikologis lebih matang dan stabil.

Beberapa penelitian menjelaskan burnout cenderung tinggi pada pekerja muda, dimana pekerja muda cenderung memiliki cara berpikir belum cukup realistis terhadap pekerjaan. Hal ini cukup sejalan dengan hasil penelitian, dimana sampel penelitian usianya $70 \%$ diatas 40 tahun, menunjukkan hasil yakni sindrom burnout termasuk rendah. Tumipsteed (dalam Eliyana, 2018) mengatakan seorang yang telah bekerja pada satu bidang pekerjaan untuk waktu yang lama maka dia cenderung telah memiliki pandangan yang realistis terhadap situasi yang dihadapi. Disamping itu, Lee (dalam Eliyana 2018) menjelaskan perawat dengan minim pengalaman mengakibatkan mudah mengalami burnout. Hal ini semakin mendukung hasil penelitian yang menunjukkan tingkat burnout rendah, dimana perawat yang diteliti sebagian besar berpengalaman diatas 10 tahun. Disamping itu, sampel penelitan adalah PNS (pegawai negri sipil), pegawai tetap yang penghasilannya secara konsisten terjamin sehingga bisa dikatakan tingkat kenyamanan fiancialnya termasuk cukup baik.

Ditinjau dari aspek psychological well-being, sampel penelitian terukur pada level yang cukup baik, dimana 63 $\%$ pada kategori tinggi dan $37 \%$ pada kategori sedang, tidak ada pada kategori rendah. Karakteristik sampel penelitian cukup mendukung tingginya psychological well-being dimana sampel merupakan karyawan PNS yang sudah lama masa kerjanya, dengan demikian kesejahteraan karir dan financial termasuk cukup memadai, dimana ini merupakan salah satu indikator penting psychological well-being (Rath dan Harter 2010, dalam Hefferon dkk).

Pengukuran dalam penelitian ini menggunakan skala sikap yang bisa saja belum cukup menjelaskan secara komprehensif terkait kualitas kesejahteraan psikologis peserta penelitian. Namun demikian bisa menggambarkan penghayatan mereka tentang kondisi psychological well-being saat ini. Dimana jika ditinjau dari masing-masing aspek psychological well-being, yang berkorelasi negative dengan burnout adalah aspek autonomi, tujuan hidup dan penerimaan diri. Sedangkan kepuasan dalam menjalin relasi social, pertumbuhan pribadi dan penguasaan lingkungan tidak berkorelasi signifikan dengan burnout. Dengan demikian aspek autonomi, tujuan hidup dan penerimaan diri yang berhubungan dalam berkembangnya sindrom burnout, sedangkan aspek lainnya kurang berperan. Dengan demikian ada baiknya penelitian lebih lanjut untuk bisa lebih menjelaskan situasi tersebut. Dimana teknik penelitian bisa diarahkan lebih ke kualitatif, misalnya wawancara mendalam.

Disamping itu, perawat yang diteliti merupakan perawat-perawat yang sudah cukup matang ditinjau dari usia, pengalaman kerja bahkan juga penghasilan, maka bisa saja fenomena 
burnout bisa muncul lebih besar jika di teliti pada perawat yang usianya lebih muda atau junior. Begitu juga gejala psychological well-being bisa berbeda hasilnya jika diteliti pada perawat dengan karakterisitk yang usianya lebih muda atau junior, yang cenderung masih penuh dengan idealisme.

\section{KESIMPULAN DAN SARAN}

Kesimpulan dari penelitian ini antara lain:

1. Psychological well-being perawat di Rumah Sakit Jiwa Pemprovsu Medan termasuk cukup baik karena berada pada tingkat sedang dan tinggi. yakni pada tingkat sedang (37\%) dan tingkat tinggi $(67 \%)$.

2. Tingkat Burnout pada perawat di rumah sakit jiwa Pemprovsu Medan, berada pada kategori rendah, dimana pada gejala kelelahan emosional semua perawat pada level rendah; sementara pada gejala depersonalisasi dan kemampuan efektifitas kerja hampir semua perawat pada level rendah. Ada beberapa perawat yang berada pada level moderate hingga tinggi pada dimensi depersonaliasi dan efektifitas.

3. Adanya hubungan yang signifikan antara Psychological well-being terhadap tingkat Burnout pada perawat di Rumah Sakit Jiwa Pemprovsu dimana arah hubungannya bersifat negative.

4. Ada 3 (tiga) aspek Psychological well-being yang menunjukkan hubungan signifikan terhadap tingkat Burnout yakni aspek autonomi, tujuan hidup dan penerimaan diri; sementara 3 (tiga) aspek lainnya (pertumbuhan pribadi, penguasaan lingkungan dan relasi yang positif) tidak menunjukkan hubungan yang signifikan terhadap tingkat Burnout pada perawat di Rumah Sakit Jiwa Pemprovsu Medan.

\section{Saran}

1. Penelitian selanjutnya

- Perlunya dilakukan penelitian lebih lanjut tentang korelasi Psychological well-being terhadap Burnout pada perawat jiwa yang usianya lebih muda.

- Perlunya dilakukan penelitian lebih lanjut terkait PWB dan burnout dengan teknik penggalian data kualitatif.

2. Praktis

- Pihak rumah sakit perlu melakukan intervensi secara serius untuk membantu perawat-perawat yang menunjukkan gejala Burnout yang sudah pada level moderat, apalagi yang level tinggi.

- Pihak rumah sakit agar memikirkan untuk menciptakan lingkungan kerja yang membantu untuk meminimalkan berkembang sindrom Burnout dan memaksimalkan Psychological wellbeing perawat, misalnya melakukan acara gathering/rekreasi, olah raga. Disamping itu juga mampu menyiapkan support system, yakni memberikan apresiasi/ penghargaan positif untuk perawat-perawat yang mampu memberikan pelayanan yang baik kepada pasien.

\section{DAFTAR PUSTAKA}

Arikunto, Suharsimi. (2002). Prosedur Penelitian: Suatu Pendekatan Praktek, Jakarta: PT. RINEKA CIPTA.

Ambarita, Togi F. A., (2017) Perbedaan Burnout antara tipe kepribadian introvert dan tipe kepribadian ekstrovert pada perawat di ruangan Critical Care, Jurnal Generasi Kampus. 
Azwar, Saifuddin Penelitian,Yogyakarta: PUSTAKA PELAJAR.

Eliyana (2016). Faktor - Faktor yang Berhubungan dengan Burnout Perawat Pelaksana di Ruang Rawat Inap RSJ Provinsi Kalimantan BaratTahun 2015, Jurnal ARSI/Juni 2016 vol 2 no. 3.

Feist, Jess \& Feist, Gregory. (2010). Teori Kepribadian. Buku $2 . \quad$ Jakarta: Salemba Humanika.

Hefferon, K and Boniwell, I (2011). Positive Psychology Theory, Research and Applications, McGraw-Hill

Kholifah, S., Setyawati, S., Lilik, S. (2012). Hubungan faktor-faktor internal dengan kejadian kelelahan mental (burnout) pada perawat, J.K.Mesencephalon, Vol.2 No.4, Oktober 2016, hlm 251-259.

Maslach, C., \& Leiter, M. P. (1997). The Truth About Burnout, San Fransisco: Josseybass.

Maslach, C., Schaufeli W.B. \& Leiter, M. P. (2001,Mei). Issue:Annual Job Burnout. www.AnnualReviews.org.

Matta., Anzi (2016). Kesehatan Mental di Indonesia Hari ini. https://tirto.id/kesehatan-mental-diindonesia-hari-ini-b9tw

Nugroho, AS., Pramadi, A., Tondok, M.S. (2012). Studi Deskriptif Burnout dan Coping Stres pada Perawat di Ruang Rawat Inap Rumah Sakit Jiwa Menur Surabaya, Calyptra: Jurnal Ilmiah Mahasiswa Universitas Surabaya Vol.1 No.1

Pandya, M. M., \& Korat N. R. (2015). Personality Traits and Psychological Well-Being among Youths of Rajkot District.

Ryff, C. D. (1989). Happiness is everything, or is it? Explorations on the meaning of psychological well-being. Journal of Personality and Social Psychology, 57, 1069-1081.
Ryff, C. D., \& Keyes, C. L. M. (1995). The structure of psychological well-being revisited. Journal of Personality and Social Psychology.

Seligman, Martin E.P. (2002). Authentic Happiness: Using the New Positive Psychology to Realize Your Potential for Lasting Fulfillment. New York, NY: Free Press.

Singh, A.K., Singh, S., \& Sing A. P. (2012). Does Trait Predict Psychological Well-Being among Student of Professional Course. Journal of the indian Academy of Applied Psychology. Vol. 38, No.2.

Siswati (2018). Hubungan antara emotional labor dengan psychological wellbeing pada perawat rsjd dr. Amino gondohutomo semarang, Jurnal Empati, Agustus 2018, Volume 7 (Nomor 3), Halaman 27-32.

Sekaran, U., \& Bougie, R. (2016). Research Methods for Business. United Kingdom. John Wiley \& Sons.

Schaufeli, W.M. \& Buunk,B.P. (1996). Professional Burnout, dalam Schabrac, M.J. \& Winnubst, J.A.M.(Vol Ed), Handbook of Work and Helath Psychology John. Wiley $\&$ Sons

Schulz, D. \& Sydney, E. (1993). Theories of Personality edisi ke-5, California: Brooks Publishing Company.

Sugiyono,(2008). Metode penelitian Kuantitatif dan Kualitatif. $R \& D . \quad$ Bandung. Alfabeta.

Suryabrata, S. (2000). Pengembangan Alat Ukur Psikologi, Yogyakarta: Andi Offset.

Sutjipto (2001). Apakah anda Mengalami Burnout, dala www.Depdiknas.go.id

Triyana (2020). Gambaran burnout pada perawat kesehatan jiwa, Jurnal Keperawatan Abdurrab, Vol 3 No 2 (2020): Vol 3 No. 2 (Januari 2020). 
JURNAL PSIKOLOGI UNIVERSITAS HKBP NOMMENSEN VOL 6 NO (2) 2020 || e-issn : 2686-4908 || February 2020 91 